\title{
HAZARDS OF STEROIDS IN ASSOCIATION WITH ANAESTHESIA
}

\author{
Tsutomu Oyama, M.D.*
}

SHock on HYPOTENSION under operative stress due to adrenal failure following steroid therapy is now well recognized. ${ }^{1-3}$ Confirmation that such episodes are attributable to adrenal failure can come only from a study of plasma cortisol levels during shock or hypotension. Direct evidence of this has been scanty and difficult to acquire.

There are several points to be resolved: (a) Do we frequently observe arterial hypotension during or after operative stress in patients previously treated with steroid when no steroid is given? $(b)$ Is the operative hypotension the result of real adrenal insufficiency? $(c)$ What are the factors which contribute to adrenal failure under surgical stress? Do they include the duration of steroid treatment, the dosage, the method of administration? The present study was undertaken to investigate these problems by determining plasma cortisol (= hydrocortisone) levels during anaesthesia and operation in patients treated with steroid.

\section{METHOD}

Fourteen patients who underwent various operations were studied as shown in Table I. These patients had been treated with steroids at some period up to 297 days prior to operation. None of them received steroids on the day before operation or on the day of surgery. A group of ten patients who had no history of steroid therapy in the past and who had operations served as a control.

Each patient in both groups was premedicated with pentobarbital $50-100 \mathrm{mg}$ orally at night and $1 \frac{1}{2}$ hours prior to the induction of anaesthesia. Meperidine $35 \mathrm{mg}$ and atropine $0.5 \mathrm{mg}$ were given by intramuscular injection $1^{1 \frac{1}{4}}$ hours before the induction of anaesthesia. Due to the diurnal variations of the concentration of free cortisol in the plasma in man, induction of anaesthesia was started at 8:30 A.M. Anaesthesia was induced with halothane (0.5-2 per cent), nitrous oxide $(2 \mathrm{~L} / \mathrm{m})$, and oxygen $(2 \mathrm{~L} / \mathrm{m})$ under a mask, followed by succinylcholine chloride (scc) $40 \mathrm{mg}$ intravenously for endotracheal intubation. Anaesthesia was maintained with halothane, nitrous oxide, and oxygen, combined with intermittent scc injection whenever needed. Ventilation was controlled or assisted throughout the procedure. A moderate depth of anaesthesia was maintained during each procedure by clinical judgment and occasional electroencephalographic monitoring.

Determination of free cortisol (17-hydroxycorticosteroid $=17$-oHcs) concentration in the plasma was made for $1 \mathrm{ml}$ of plasma by Rudd's fluorimetric method $^{4}$ with a Farrand spectrofluorimeter, using an activating wavelength of 470 $\mathrm{m} \mu$ and a fluorescent wavelength of $530 \mathrm{~m} \mu$. Two determinations were made on

'Department of Anaesthesiology, Hirosaki University School of Medicine, Hirosaki, Japan.

Can. Anaes. Soc. J., vol. 16, no. 5, September 1969 


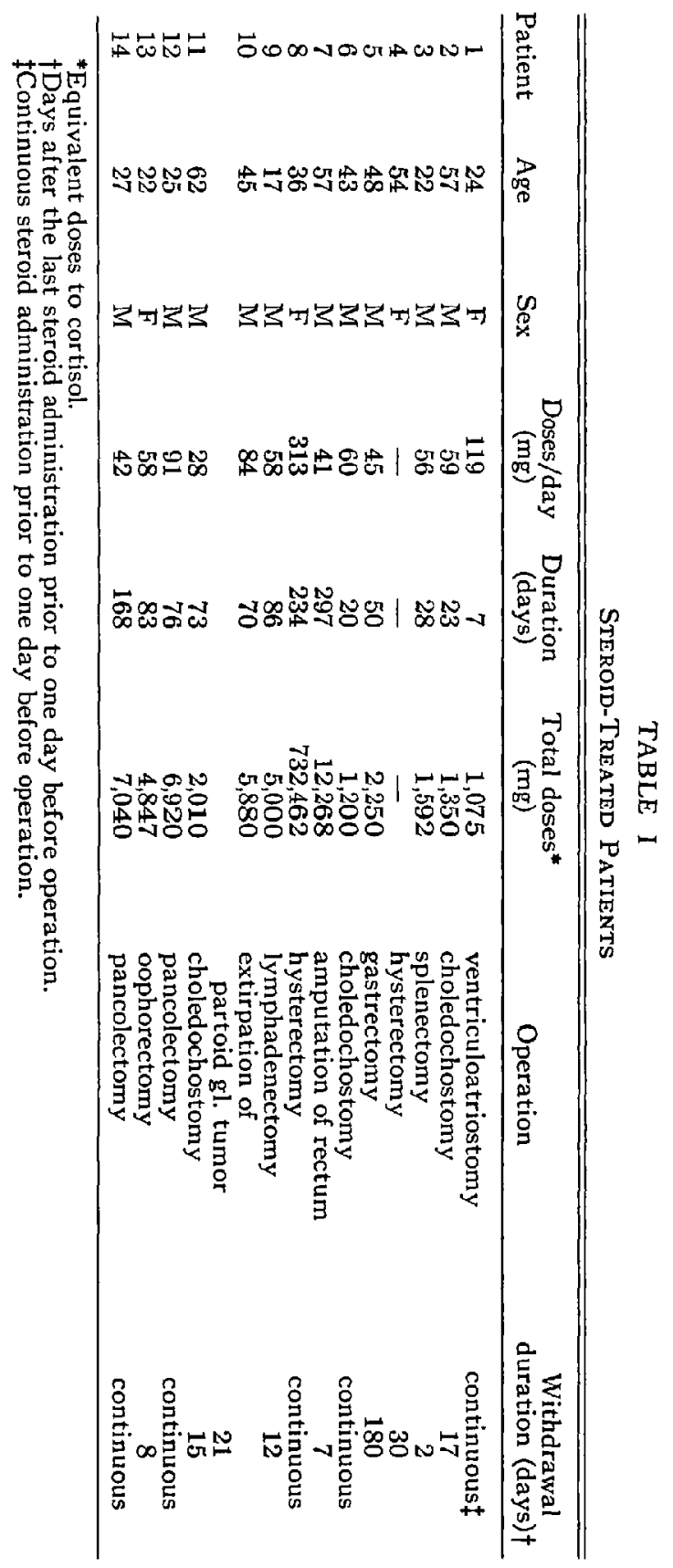


each sample and the mean value was taken. The duplicate error was $\pm 1.2 \mu \mathrm{g}$ per $100 \mathrm{ml}$ of plasma, which appeared to be reliable for analysing our data.

The blood sampling time was as follows: $(a)$ the day before surgery at $4-5$ PM, $(b)$ immediately before induction of anaesthesia, $(c)$ after 30 to 45 minutes of halothane anaesthesia alone, (d) 30 minutes after start of surgery, ( $e$ ) one to two hours after start of surgery, $(f)$ in the recovery room when the patient was considered to be fully awake.

\section{Results}

Preanaesthetic level. The mean plasma level of free cortisol in the evening of the day before operation was $9.3 \pm 1.3 \mu \mathrm{g}$ per $100 \mathrm{ml}$ ( $\pm=\mathrm{SE}$ ) for the steroid treated patients and $9.5 \pm 1.2 \mu \mathrm{g}$ per $100 \mathrm{ml}$ for the control group. These values were within normal limits at the resting level under non-stressful conditions in the evening in our laboratory. ${ }^{5}$ In the steroid treated group the mean preanaesthetic level of free cortisol at 8:30 AM on the day of operation was $10.7 \mu \mathrm{g}$ and was lower than the control group $(10.8 \mu \mathrm{g})$, but the difference was not statistically significant (Tables II and III).

Plasma levels during anaesthesia. In the 14 patients to whom steroids had been given, the mean concentration after 30 minutes of halothane anaesthesia actually did not change from preinduction values (Table II). In the control patients, the corresponding mean value significantly increased to $17.5 \pm$ $1.6 \mu \mathrm{g}$ from the mean preinduction value of $10.8 \pm 1.4 \mu \mathrm{g}$ per $100 \mathrm{ml}(t=2.84$, $p<0.01$ ). In the steroid treated patients average free cortisol levels in the plasma further decreased to $7.8 \pm 1.4 \mu \mathrm{g}$ after 45 minutes of halothane anaesthesia. These variations after 30 minutes of anaesthesia in comparison with the preinduction con-

TABLE II

Free Plasma Cortisol Levels $(\mu \mathrm{g} / 100 \mathrm{ml}$ ) of Steroid-Treated Patients during Halothane AnaEsthesia and Surgery

\begin{tabular}{|c|c|c|c|c|c|c|c|c|}
\hline Patient & $\begin{array}{c}\text { Pre- } \\
\text { premed. }\end{array}$ & $\begin{array}{l}\text { Pre- } \\
\text { ind. }\end{array}$ & $\begin{array}{l}\text { Anaes. } \\
30 \text { min. }\end{array}$ & $\begin{array}{l}\text { Anaes. } \\
45 \text { min. }\end{array}$ & $\begin{array}{c}\mathrm{Op}_{\mathrm{p}} \\
30 \mathrm{~min} .\end{array}$ & $\begin{array}{c}\text { Op. } \\
60 \mathrm{~min} .\end{array}$ & $\begin{array}{c}\text { Op. } \\
120 \mathrm{~min} .\end{array}$ & $\begin{array}{l}\text { Recovery } \\
\text { room }\end{array}$ \\
\hline 1 & 10.0 & 4.3 & 13.5 & 7.6 & - & - & 13.5 & - \\
\hline 2 & 13.7 & 4.2 & 0 & 0 & - & 20.0 & 17.9 & 24.0 \\
\hline 3 & 8.9 & 7.3 & 11.1 & - & 15.7 & 14.8 & 22.8 & 28.6 \\
\hline 4 & 12.5 & 15.0 & 15.5 & - & 20.0 & 18.5 & 23.5 & 25.0 \\
\hline 5 & 7.8 & 3.3 & 6.1 & 7.8 & 20.0 & 21.1 & 33.3 & 27.8 \\
\hline 6 & 4.3 & 16.2 & $13 . \overline{7}$ & 10.0 & 9.3 & 6.2 & 10.6 & 9.3 \\
\hline 7 & 4.2 & 5.8 & 8.1 & 9.0 & 11.8 & 12.6 & 15.5 & 20.7 \\
\hline 8 & 1.2 & 1.0 & 2.5 & 3.0 & - & 7.0 & - & 8.5 \\
\hline 9 & 19.5 & 18.3 & - & - & 17.9 & 12.2 & 22.0 & 39.5 \\
\hline 10 & 10.0 & 17.5 & 15.0 & 13.8 & 11.3 & 11.3 & 11.3 & 7.5 \\
\hline 11 & 8.0 & 18.0 & 14.0 & 6.0 & 9.0 & 9.0 & 11.0 & 14.8 \\
\hline 12 & - & 4.5 & 7.0 & - & - & 11.5 & 26.0 & 28.5 \\
\hline 13 & 11.4 & 14.2 & 14.3 & 12.6 & 8.3 & 8.3 & 8.0 & 6.5 \\
\hline 14 & . & 20.0 & 20.0 & & 21.0 & 40.0 & - & - \\
\hline Mean & 9.3 & 10.7 & 10.8 & 7.8 & 14.4 & 14.8 & 18.0 & 20.1 \\
\hline $\mathrm{SE}$ & 1.3 & 1.8 & 1.5 & 1.4 & 1.5 & 2.5 & 2.1 & $2 . \overline{9}$ \\
\hline$t^{*}$ & 0.59 & - & 0.04 & 1.12 & 1.43 & 1.29 & 2.65 & 2.82 \\
\hline$p^{*}$ & - & - & - & - & $\therefore$ & - & $<0.02$ & 0.01 \\
\hline
\end{tabular}

${ }^{*}$ Compared with mean preinduction value. 
centrations represent a statistically significant difference $(p<0.01)$ in the control group, but not a significant change in the steroid treated patients. Moreover, the mean level of the control group was almost twice as high as that of the steroid treated group and the difference was statistically significant $(p<0.01)$, as shown in Table III.

\section{TABLE III}

Comparison of Mean Free Plasma Cortisol Levels ( $\mu \mathrm{g} / 100 \mathrm{ml}$ ) of Control and Steroid-Treated Patients during Halothane Anaesthesia and Surgery

\begin{tabular}{|c|c|c|c|c|c|c|c|c|}
\hline \multirow[b]{2}{*}{ Patient } & \multicolumn{8}{|c|}{ Time in minutes } \\
\hline & $\begin{array}{c}\text { Pre- } \\
\text { premed. }\end{array}$ & $\begin{array}{l}\text { Pre- } \\
\text { ind }\end{array}$ & $\begin{array}{l}\text { Anaes. } \\
30 \mathrm{~min} \text {. }\end{array}$ & $\begin{array}{l}\text { Anaes. } \\
45 \text { min. }\end{array}$ & $\begin{array}{c}\text { Op. } \\
30 \mathrm{~min} .\end{array}$ & $\begin{array}{c}\text { Op. } \\
60 \mathrm{~min} .\end{array}$ & $\begin{array}{c}\text { Op. } \\
120 \mathrm{~min} .\end{array}$ & $\begin{array}{c}\text { Recovery } \\
\text { room } \dagger\end{array}$ \\
\hline $\begin{array}{c}\text { Control } \\
(10) \\
\text { Steroid } \\
(14)\end{array}$ & $\begin{array}{r}9.5 \\
\pm 1.2^{*} \\
9.3 \\
\pm 1.2\end{array}$ & $\begin{array}{r}10.8 \\
\pm 1.4 \\
10.7 \\
\pm 1.8\end{array}$ & $\begin{array}{r}17.5 \\
\pm 1.6 \\
10.8 \\
\pm 1.5\end{array}$ & $\begin{array}{r}- \\
\overline{7.8} \\
\pm 1.4\end{array}$ & $\begin{array}{r}\overline{-} \\
14.4 \\
\pm 1.5\end{array}$ & $\begin{array}{r}26.3 \\
\pm 1.8 \\
14.8 \\
\pm 2.5\end{array}$ & $\begin{array}{r}31.7 \\
\pm 2.2 \\
18.0 \\
\pm 2.1\end{array}$ & $\begin{array}{r}32.7 \\
\pm 2.2 \\
20.1 \\
\pm 2.9\end{array}$ \\
\hline $\begin{array}{l}t \\
p\end{array}$ & $\underline{0.05}$ & $\frac{0.04}{-}$ & $\begin{array}{r}2.84 \\
<0.01\end{array}$ & $=$ & - & $\begin{array}{r}3.25 \\
<0.01\end{array}$ & $\begin{array}{c}4.11 \\
<0.001\end{array}$ & $\begin{array}{r}3.15 \\
<0.01\end{array}$ \\
\hline
\end{tabular}

*Standard error of the mean.

†Patients were adequately awake in the recovery room.

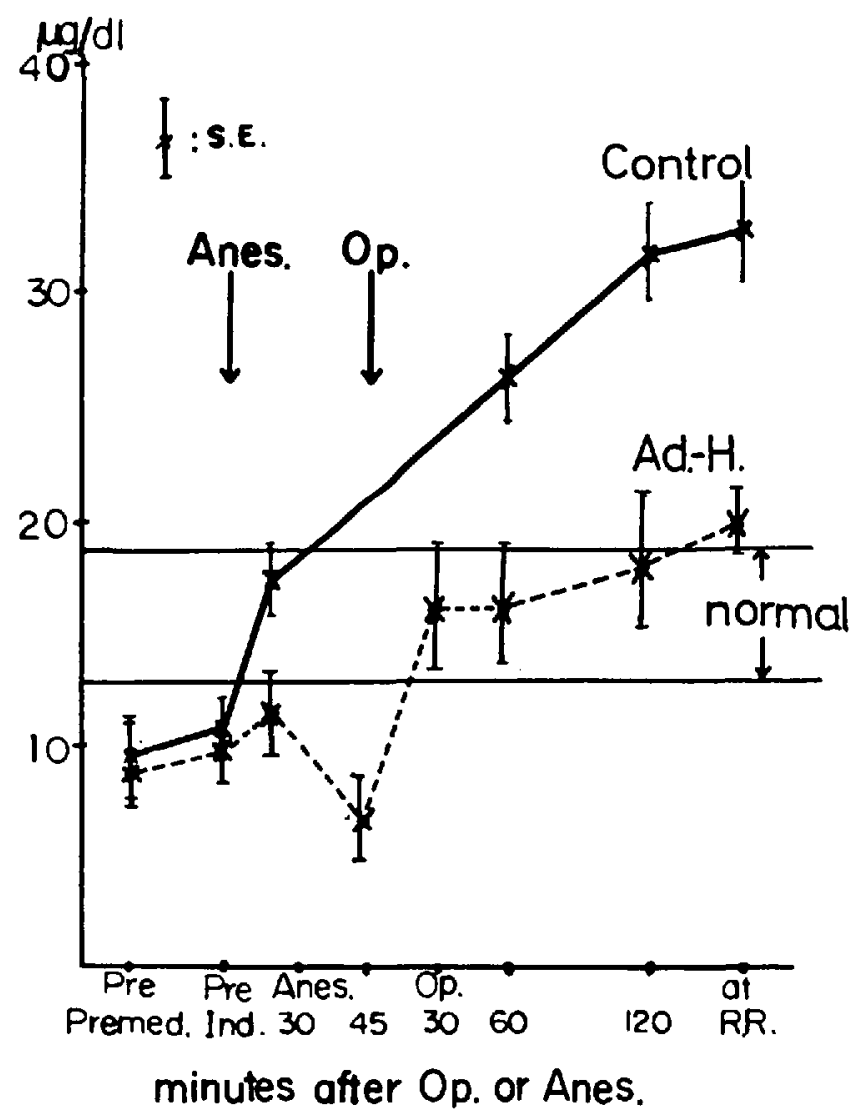

Ficure 1. Free plasma 17-oncs levels. 
Plasma levels during surgery. In the fourteen steroid treated patients, the mean cortisol levels in the plasma at one hour after starting surgery was $14.8 \pm$ $2.5 \mu \mathrm{g}$ per $100 \mathrm{ml}$. It was $26.3 \pm 1.8 \mu \mathrm{g}$ per $100 \mathrm{ml}$ in the ten control patients (Table III, Fig. 1). These increases above the preinduction concentrations represent a statistically significant difference $(p<0.01)$ in the control group, but not a significant change in the steroid treated group. Furthermore, the mean level in the former was almost twice as high as in the latter, and its difference was statistically significant $(p<0.01)$ (Table III).

\section{CASE No. 7}

A fifty-seven-year-old male patient underwent rectal resection for rectal cancer. His plasma free cortisol level in the evening of the day before operation was very low $(4.2 \mu \mathrm{g})$. It was still as low as $5.8 \mu \mathrm{g}$ at 8:30 AM just prior to the induction of anaesthesia. It increased slightly to $8.1 \mu \mathrm{g}$ after 30 minutes of halothane anaesthesia. As illustrated in Figure 2 the arterial blood pressure decreased from 150 to $80 \mathrm{~mm} \mathrm{Hg}$ within 20 minutes of starting surgery, when the plasma free cortisol level was very low at $11.8 \mu \mathrm{g}$. Blood loss was about $50 \mathrm{ml}$ at that time, and vasopressor (Effortil $2 \mathrm{mg}$ ) was administered intravenously. Within 20 minutes arterial blood pressure rose to $140 \mathrm{~mm} \mathrm{Hg}$.

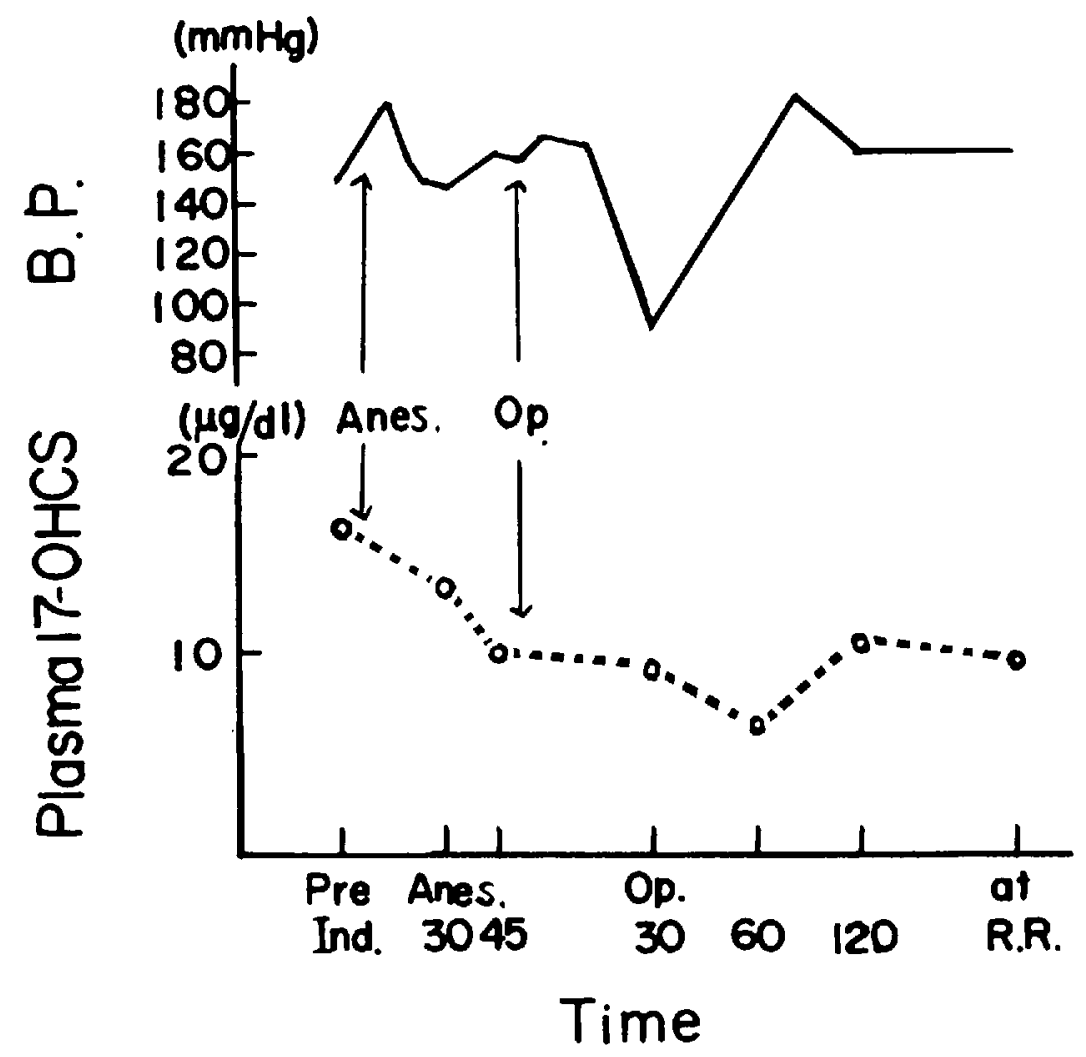

Figune 2. Plasma 17-ohcs levels and systolic blood pressure. 
This patient had been under steroid treatment (dexamethasone $1.0 \mathrm{mg}$ per day) for 170 days. After discontinuing treatment for three months, he took dexamethasone $0.75 \mathrm{mg}$ per day for 40 days, then $1.0 \mathrm{mg}$ per day for five months and prednisolone $30 \mathrm{mg}$ per day for ten days up to a week prior to surgery. Thus the total steroid used by him was equivalent to $12.26 \mathrm{gm}$ of cortisol.

\section{Discussion}

Patients with adrenocortical insufficiency have been suspected to be increasing in number because of the increased therapeutic use of adrenal steroids for a number of diseases and performance of adrenalectomy or hypophysectomy for treatment of certain cancers. This has produced a growing probability of encountering adrenal crisis during or after anaesthesia and surgery, characterized mainly by arterial hypotension and tachycardia and terminating in shock and death.

Adrenocortical insufficiency during or after surgery has rarely been documented. Many hypotensive patients have had satisfactory responses to the administration of corticoids along with other measures and this has been interpreted as establishing the diagnosis of adrenocortical failure, with no proof other than the response to therapy. ${ }^{6-16}$ In many of these cases, which superficially resemble adrcnal insufficiency, the patients recover after the correction of blood loss or injection of vasopressor. Cope ${ }^{3}$ called this sort of case a pseudohypoadrenalism. Mattingly and Tyler ${ }^{23}$ collected 14 operative and 23 medical emergency cases of patients who had previously had steroids and who collapsed. Their plasma cortisol levels were within normal limits $(20 \mu \mathrm{g})$ and were recovered by injections of cortisol. Therefore, the usual operative hypotension in these patients does not seem to be the result of adrenal insufficiency as in our case (no. 7), and the postoperative collapse is very rarely associated with a low plasma cortisol. For these reasons it is of paramount importance to measure adrenocortical function during hypotensive episodes in patients who have a past or present history of receiving steroid therapy.

In seven out of fourteen patients in our series the low plasma free 17-oucs levels (1.0-7.3 $\mu \mathrm{g}$ per $100 \mathrm{ml}$ ) were observed in the preinduction period on the morning of the day of surgery. During halothane- $\mathrm{N}_{2} \mathrm{O}$ anaesthesia alone for 45 minutes, we found low plasma cortisol levels $(0-9 \mu \mathrm{g}$ per $100 \mathrm{ml})$ in seven out of fourteen patients (nos. 2, 5, 6, 7, 8, 11, 12). Arterial hypotension occurred in five patients (nos. 6, 7, 8, 11, 14). Except for one case (no. 14), plasma cortisol levels during 45 minutes of anaesthesia alone were low (less than $10 \mu \mathrm{g}$ per 100 $\mathrm{ml}$ ) in all these cases. However, so far as the timing of hypotension is concerned, it is not necessary that the lowest plasma cortisol level correspond in time with the arterial hypotension. Moreover, we did not find arterial hypotension in three patients (nos. 2, 5, 12) who had low plasma cortisol levels during halothane anaesthesia alone for 30 minutes. As mentioned before, our data would suggest that the low plasma free cortisol levels in the peripheral venous blood during anaesthesia or surgery are not necessary to represent arterial hypotension, and 
vice versa in the steroid treated patients. It is of interest to note that in four out of five of these hypotensive patients, steroid therapy had been continued until one to seven days prior to operation (Table I).

It has been widely recommended that patients receiving steroids within two years of operation should receive steroid cover to prevent adrenal failure. ${ }^{13}$ Vandam and Moore ${ }^{1}$ stated that any patient who has been on cortisone therapy for four days or longer or cortisone therapy within the past six months may be considered to have subnormal adrenocortical function. Danowski et al. ${ }^{24}$ observed that as much as $300 \mathrm{mg}$ of cortisol daily for 30 days had no detectable effect on the ACTH response. According to them, after courses lasting a year or more spontaneous revival of adrenocortical activity will usually occur within 48 hours. There seems to be fairly general agreement that the pituitary-adrenal axis is little disturbed after short courses of steroid therapy. ${ }^{3,19,24}$

However, we must not use conclusions on adrenal recovery to predict an adequate reaction to stress. The response to severe stress calls for greater corticotrophin release than does the restoration or maintenance of normal adrenal activity. Subjected to severe stress, a normally responsive adrenal should raise the cortisol to above $30 \mu \mathrm{g} / 100 \mathrm{ml}$ and in extreme cases to above $100 \mathrm{ml}$. It is said that operative stress needs as much as two to seven times the resting level of plasma cortisol. ${ }^{\mathbf{3}}$ Therefore, the pituitary-adrenal axis, when damaged by longcontinued steroid therapy, will be inadequate for the demands of stress even though normal activity may be well within its scope. It has seemed reasonable to cover all such patients, thus providing steroids unnecessarily for many to safeguard the few..$^{1,11,13}$ However, the increased incidence of infection is to be seriously considered. ${ }^{17}$

Analysing our data, we find that the duration of administration and doses of corticosteroids were variable; therefore it is quite difficult to draw a definite conclusion from our data. It appears reasonable to say that real adrenocortical failure is rare, and the hypotensive episodes during anaesthesia or surgery are not necessarily to be attributed to adrenocortical insufficiency.

From a review of our data and 40 other adrenal crises during or after operation reported in the literature, ${ }^{2,6-22}$ the following points emerge: $(a)$ In thirty-two per cent of the total cases reported the patient had been treated wih steroid for less than one month, and in 62 per cent for less than six months. (b) The total dose of steroid used (equivalent to cortisol) was less than $1 \mathrm{gm}$ in only one patient. This indicates that it is rare to find so-called adrenal failure in the patient whose total steroid prior to operation was less than $1 \mathrm{gm}$. (c) Only five patients had received daily doses of steroid equivalent to less than $25 \mathrm{mg}$ of cortisol: this suggests that patients whose daily dose of cortisol was less than $25 \mathrm{mg}$ have fewer episodes of arterial hypotension than those whose daily dose of cortisol was more than 25 mg. (d) Most of the reported cases ( 70 per cent) occurred in the early period between 1952 and 1958 when intermittent or small dose maintenance regimens were not established. (e) Twenty-six patients ( 60 per cent) had been treated with steroid either continuously or within one week prior to operation, but none of them received steroid on the day of operation. 
Analysing these data, the present author proposes a method of preoperative and postoperative steroid administration as shown in Tables IV to VII to prevent adrenal failure in patients who have had steroid treatment and are undergoing operation. The equipotent adrenocortical preparations are shown in Table VIII.

TABLE IV

Patients Needing Steroid Cover Prior to Operation

1. Patients now under treatment with steroid.

2. Patients with a history of continuous steroid treatment for more than one month within six months prior to operation.

3. Patients who have received total steroid equivalent to more than $1 \mathrm{gm}$ of cortisol within six months prior to operation.

4. Patients undergoing adrenalectomy or hypophysectomy or with history of operation for these endocrine organs.

5. Addisonian patients.

TABLE V

Method of Steroid Administration for Elective Cases

\begin{tabular}{|c|c|c|}
\hline Time & Dose & Route \\
\hline Day before operation & $\begin{array}{l}\text { cortisone } \\
100 \sim 200 \mathrm{mg}\end{array}$ & $\begin{array}{l}\text { intramuscular AM and pul } \\
\text { divided into two doses }\end{array}$ \\
\hline Immediately before anaesthetic & $\begin{array}{l}\text { hydrocortisone } \\
100 \mathrm{mg}\end{array}$ & intramuscular \\
\hline During operation & $\begin{array}{l}\text { hydrocortisone } \\
100 \sim 200 \mathrm{mg}\end{array}$ & $\begin{array}{l}\text { intravenous drip in } 500 \mathrm{nll} \text { of } \\
\text { blood or } 5 \% \text { dextrose in water }\end{array}$ \\
\hline Immediately after operation & $\begin{array}{l}\text { hydrocortisone } \\
100 \mathrm{mg}\end{array}$ & intramuscular \\
\hline
\end{tabular}

TABLE VI

Method of Steroid Administration for Emergency Cases

\begin{tabular}{lll}
\hline \multicolumn{1}{c}{ Time } & \multicolumn{1}{c}{ Dose } & \multicolumn{1}{c}{ Route } \\
\hline Immediately before operation & hydrocortisone & intramuscular \\
& $100 \sim 200 \mathrm{mg}$ & intravenous drip in $500 \mathrm{ml}$ \\
During operation & hydrocortisone & blood or $5 \%$ dextrose in water \\
& $200 \mathrm{mg}$ & intramuscular \\
Immediately after operation & hydrocortisone & \\
& $100 \mathrm{mg}$ & \\
\hline
\end{tabular}

TABLE VII

Postoperative Administration of Steroid for Steroid-Treated Patient

\begin{tabular}{lcrrr}
\hline \hline \multirow{2}{*}{$\begin{array}{c}\text { Date } \\
\text { (postop.) }\end{array}$} & $\begin{array}{c}\text { Total dose } \\
\text { (ng) }\end{array}$ & \multicolumn{3}{c}{ Intramuscular injection $(\mathrm{mg})$} \\
\cline { 3 - 5 } & 8 PM & 3 PM & 8 PM \\
\hline 1st day & 200 & 100 & 50 & 50 \\
2nd day & 150 & 75 & 50 & 25 \\
3rd day & 100 & 50 & 25 & 25 \\
4th day & 50 & 25 & 25 & 0 \\
5th day & 25 & 25 & 0 & 0 \\
6th day & 25 & 25 & 0 & 0 \\
7th day & 0 & 0 & 0 & 0 \\
\hline
\end{tabular}


TABLE VIII

\begin{tabular}{lll}
\multicolumn{3}{c}{$\begin{array}{c}\text { Drugs of ADrenocortical } \\
\text { (GlucocorTicoid) }\end{array}$} \\
\hline \multicolumn{1}{c}{ Drug } & $\begin{array}{c}\text { Clinical } \\
\text { effect }\end{array}$ & $\begin{array}{c}\text { Equivalent } \\
\text { dose (mg) }\end{array}$ \\
\hline Cortisol & & \\
$\quad$ (hydrocortisone) & 1.0 & 20 \\
Cortisone & 0.8 & 25 \\
Prednisolone & 4 & 5 \\
Prednisone & 3.5 & 5 \\
Methyl-prednisolone & 5 & 4 \\
Triamcinolone & 5 & 4 \\
Dexamethasone & 30 & 0.75 \\
Paramethasone & 10 & 1.5 \\
Betamethasone & 35 & 0.5 \\
\hline
\end{tabular}

\section{Summary AND CONCLUSION}

The present study was undertaken to investigate the correlation between arterial hypotension during anaesthesia or operation and adrenocortical hypofunction in 14 patients previously treated with steroid. None of these patients received steroids on the day before operation or on the day of surgery. A group of ten patients who had no history of receiving steroid therapy and who underwent operations served as a control. Both groups of patients received the same premedication and halothane- $\mathrm{N}_{2} \mathrm{O}$ anaesthesia.

The mean free cortisol level in the plasma after 30 minutes of halothane- $\mathrm{N}_{2} \mathrm{O}$ anaesthesia alone $(10.8 \pm 1.5 \mu \mathrm{g}$ per $100 \mathrm{ml}$ ) in the steroid treated patients did not change from the preinduction value $(10.7 \pm 1.8 \mu \mathrm{g}$ per $100 \mathrm{ml})$, while in the control group it increased significantly from $10.8 \pm 1.4$ to $17.5 \pm 1.4$ to $17.5 \pm 1.6$ $\mu \mathrm{g}$ per $100 \mathrm{ml}$. Plasma levels of cortisol one hour after the start of operation were insignificantly elevated $(14.8 \pm 2.5 \mu \mathrm{g}$ ) in the steroid treated patients, but in the control patients they rose significantly to $26.3 \pm 1.8 \mu \mathrm{g}$.

Arterial hypotension occurred in five steroid treated patients during anaesthesia alone or during operation, and except for one case a low level (0-9 $\mu \mathrm{g})$ of free cortisol was observed in plasma. However, it was not necessary that the timing of hypotension corresponded with the lowest plasma cortisol level. On the contrary, three other patients with low levels of plasma cortisol did not show any arterial hypotension during the procedure. These data would suggest that low plasma free cortisol levels in the peripheral venous blood during anaesthesia or surgery are not necessary to represent arterial hypotension in the steroid treated patients and vice versa.

In order to prevent a possible so-called adrenocortical insufficiency during operation in patients previously treated with steroid, the author suggests that the following patients should receive hormone preoperatively and during operation: (a) patients currently under steroid treatment; (b) patients who have had continuous treatment for more than one month in the six months prior to operation or who have received more than $1 \mathrm{gm}$ of cortisol or equivalent other stcroids. 


\section{RÉSUMÉ}

Nous avons entrepris cette étude pour trouver une corrélation entre l'hypotension artérielle durant l'anesthésie ou l'opération et l'hypofonctionnement de la surrénale chez 14 malades traités aux stéroides au préalable. La veille du jour de Popération aucun de ces malades n'a reçu de stéroides. Nous avons pris comme témoins 10 malades qui ont été opérés et qui ne présentaient aucune histoire de thérapie par stéroides. Les deux groupes de malades ont reçu la même prémédication et une anesthésie à l'halothane $\mathrm{N}_{2} \mathrm{O}$.

Le niveau moyen de cortisol libre dans le plasma après 30 minutes d'anesthésie à l'halothane $\mathrm{N}_{2} \mathrm{O}$ seulement $(10.8 \pm 1.5 \mathrm{mg}$ par $100 \mathrm{ml}$ ) chez les malades traités n’a pas changé si on le compare au niveau trouvé avant l'induction ( $10.7 \pm 1.5$ $\mathrm{mg}$ par $100 \mathrm{ml}$ ) alors que, chez les témoins, le niveau a augmenté de $10.8 \pm 1.4 \mathrm{~d}$ $17.5 \pm 1.4$ à $17.5 \pm 1.6 \mathrm{mg}$ par $100 \mathrm{ml}$. Une heure après le début de l'opération, les niveaux de cortisol plasmatique étaient légèrement plus élevés $(14.8 \pm 2.5$ mg) chez les malades traités aux stéroides alors que, chez les témoins, les niveaux se sont élevés à $26.3 \pm 1.8 \mathrm{mg}$.

Une hypotension artérielle est survenue chez cinq malades traités aux stéroides durant l'anesthésie ou l'opération et, à l'exception d'un cas, on a trouvé un taux bas de cortisol libre dans le plasma $(0 \pm 9 \mathrm{mg})$. Toutefois, nous n'avons pas crû nécessaire que le plus bas niveau de cortisol plasmatique corresponde au moment de l'hypotension. Au contraire, trois autres malades possédant des niveaux de cortisol plasmatique bas n'ont pas présenté, au cours de l'opération, de phases d'hypotension artérielle. Ces résultats nous permettent de croire que des niveaux de cortisol plasmatique libre bas dans le sang veineux périphérique au cours de l'anesthésie et de la chirurgie ne représentent pas necessairement une hypotension artérielle chez des malades traités aux stéroides et vice-versa.

Pour prévenir, au cours d'une opération, une possibilité de ce qu'on appelle l’insuffisance surrénalienne chez des malades traités au préalable avec des stéroides, lauteur suggère que les malades suivants reçoivent des hormones avant et pendant l'opération: $(a)$ les malades actuellement sous traitement aux stéroides; $(b)$ le malade qui, au cours des six mois précédant l'opération, a reçu un traitement continuel durant plus d'un mois ou qui a reçu $1 \mathrm{gm}$ de cortisol ou l'equivalent d'autres stéroides.

\section{REFERENCES}

1. VANDAM, L. D. \& Moore, F. D. Adrenocortical Mechanism Related to Anesthesia. Anesthesiology. 21: 531 (1960).

2. Sampson, P. A.; Winstone, N. E.; \& Bnooke, B. N. Adrenal Function in Surgical Patients after Steroid Therapy. Lancet. ii: 322 (1962).

3. Cope, C. L. The Adrenal Cortex in Internal Medicine (I). Brit. Med. J. 2: 47 (1966).

4. Rudd, B. T.; Cowper, J. M.; \& Crawford, N. The Determination of Plasma Free Hydrocortisone and Corticosterone by a Combined Fluorimetric and Modified Porter-Silber Procedure. Clin. Chim. Acta. 6: 686 (1961).

5. Oyama, T.; Shubata, S.; Matsumoto, F.; Takiguchi, M.; \& Kudo, T. Effects of Halothane Anaesthesia and Surgery on Adrenocortical Function in Man. Canad. Anaesth. Soc. J. 15: 258 (1968).

6. Fraser, C. G. \& Preuss, F. S. Adrenal Atrophy and Irreversible Shock Associated with Cortisone. J.A.M.A. 149: 1542 (1952). 
7. Salassa, R. A.; Benett, W. A.; Keating, F. R.; \& Sprague, R. G. Postoperative Adrenal Cortical Insufficiency Occurrence in Patients Previously Treated with Cortisone. J.A.M.A. 152: 1509 ( 1953 ).

8. Lewiss, L.; Robinson, R. F.; Yee, J.; Hacker, L. A.; \& Eisen, G. Fetal Adrenal Cortical Insufficiency Precipated by Surgery during Prolonged Continuous Cortisone Treatment. Ann. Int. Med, 39: 116 (1953).

9. Slaney, G. \& Brooke, B. N. Postoperative Collapse Due to Adrenal Insufficiency Following Cortisone Therapy. Lancet. $i$ : 1104 (1957).

10. Harnagel, E. E. \& Kramer, W. G. Severe Adrenocortical Insufficiency Following Joint Manipulation. J.A.M.A. 158: 1518 (1955).

11. Hayes, M. A. \& Kushuan, S. O. Influence of Hormone Therapy for Ulcerative Colitis upon Course of Surgical Treatment. Gastroenterology. 30: 75 (1956).

12. Allanby, K, D. Deaths Associated with Steroid-Hormone Therapy: An Analysis of 18 Cases. Lancet. $i$ : 1104 (1957).

13. Dundes, J. W. Anaesthesia and Surgery in Adrenocortical Insufficiency. Brit. J. Anaesth. 29: 166 (1957).

14. Nicholas, J. A.; Wilson, P. D.; \& Umberger, C. J. Induced Hypoadrenalism in Patients Requiring Orthopedic Surgery. J.A.M.A. 164: 261 (1957).

15. UMEhara, S. Long Term Treatment with Corticosteroids and Its Results. Modern Medicine. 13: 1456 (1958).

16. OKaDA, K. Hypoadrenalism. Japanese J. Anesth. 9: 758 (1960).

17. Winstone, N. E. \& Brooke, B. N. Effects of Steroid Treatment on Patients Undergoing Operation. Lancet. $i: 973$ (1961).

18. Clinical Anesthesia Conference. Postoperative Acute Adrenal Cortical Insufficiency. New York State J. Med. 61: 2806 (1961).

19. Sampson, P. A.; Brooke, B. N.; \& Winstone, N. E. Biochemical Confirmation of Collapse Due to Adrenal Failure. Lancet, $i$ : 1377 (1961).

20. Motomatsu, K. Postoperative Shock in the Steroid Treated Patient. Japanese J. Anesth. II: 10 (1962).

21. Umerara, S. Adrenal Failure and Its Treatment. General Clinics. 14: 2083 (1965) (in Japanese).

22. Amakata, Y. Anesthesia for Hypoadrenalisms. Japanese J. Anesth. 15: 6 (1966).

23. Mattingl,Y, D. \& TYLER, C. Plasma 11-Hydroxy Corticoid Levels in Surgical Stress. Proc. Roy. Soc. Med. 58: 1010 (1965).

24. Danowski, T. S.; Bonessi, J. V.; Sabeb, G.; Sutton, R. D.; Webster, M. W. JR; \& SARver, M. E. Probabilities of Pituitary-Adrenal Responsiveness after Steroid Therapy. Ann. Int. Med. 61: 11 (1964). 